\title{
DIASPORY SKANDYNAWSKIE I TRANSETNICZNE PRZESTRZENIE SPOLECZNE WIKINGÓW
}

\author{
SCANDINAVIAN DIASPORAS \\ AND TRANSETHNIC SOCIAL SPACES OF VIKINGS
}

\begin{abstract}
Migrations of the Norsemen, which took place in the early Middle Ages, led to an emergence of new social formations, operating also outside Scandinavia, including "Polish" territories. These formations can be defined as diasporas or transethnic social spaces as part of the transmigration and transnational paradigms, developed with respect to sociology.
\end{abstract}

Keywords: Scandinavian, Vikings, social formation, diaspora, transethnic space.

Skandynawowie i Wikingowie pojawili się wielokrotnie na kartach publikacji autorstwa prof. Władysława Łosińskiego. Przedmiotem studiów Profesora była w pierwszej kolejności społeczność skandynawska, która osiedliła się i żyła pod koniec VIII i w IX w. nad dolną Parsętą, zamieszkując osadę w Bardach, i chowała swoich zmarłych na cmentarzysku w Świelubiu (1972; 1975). Badacz jako jeden z pierwszych przyznał, że zabytki skandynawskie odkryte na tych stanowiskach mogą być wyznacznikiem fizycznej obecności przybyszów z Północy na południowym pomorskim wybrzeżu Bałtyku (2008b). Powyższe stwierdzenie uchyliło drzwi, w tym okresie szczelnie zamknięte, dla zainicjowania studiów nad problematyką obecności skandynawskiej na naszych ziemiach w okresie wczesnego średniowiecza. Władysław Łosiński był ponadto żywo zainteresowany kwestiami migracji, kontaktów i wymiany pomiędzy społecznościami zamieszkującymi obszary nadbałtyckie, których ważnym wyznacznikiem materialnym było m.in. zjawisko dystrybucji kruszcu orientalnego (1988; 2008b).

Konsekwencją zakreślonej powyżej problematyki było zwrócenie uwagi na elity ośrodków nadbałtyckich, którym przypisano szczególną rolę w organizacji i pro-

* ORCID: 0000-0003-4513-1605; Instytut Archeologii i Etnologii PAN - Ośrodek Badań nad Kulturą Późnego Antyku i Wczesnego Średniowiecza, ul. Więzienna 6, 48-300 Wrocław, e-mail: st-wski@wp.pl. 
wadzeniu wymiany oraz określeniu ich tożsamości kulturowej i etnicznej (2008a). Znalazło to wyraz w polemice, którą podjął Władysław Łosiński z badaczem rosyjskim Glebem Seergiejewiczem Lebiediewem. Ten ostatni zaliczył ogół mieszkańców strefy nadbałtyckiej do odrębnej prowincji kulturowej, którą określił mianem nadbałtyckiej wspólnoty kulturowej. Społeczności te miałyby, w myśl tego poglądu, tworzyć wspólnotę ponadregionalną, odznaczać się poczuciem wspólnego pochodzenia, przekroczyć próg akulturacji - zarówno na poziomie kultury elitarnej, jak i kultury życia codziennego (Lebiediev 1982, s. 236-238; Łosiński 2008a, s. 126). Impulsem inicjującym jej pojawienie się miałoby być wykształcenie się sieci emporiów, rozlokowanych wzdłuż szlaku naddnieprzańskiego i nadwołżańskiego (Kirpičnikow, Dubow i Lebedev 1986, s. 189-190; Łosiński 2008a, s. 128). Władysława Łosiński sprzeciwił się powyższemu stanowisku. Jego zdaniem zjawiska i procesy kulturowe zachodzące w IX-X w. w strefie nadbałtyckiej, nie doprowadziły do powstania zunifikowanej kulturowo strefy, obejmującej ogół krajów położonych na wybrzeżach Bałtyku. Przyznał on, że dochodziło tam do różnego rodzaju zapożyczeń, ponadto wszędzie tam obowiązywały te same reguły i mechanizmy gospodarcze, jednak nie doprowadzily one do powstania ujednoliconej kulturowo strefy (2008a, s. 141).

Polemika prowadzona przez Władysława Łosińskiego z Glebem Seergiejewiczem Lebiedievem na temat modelu kultury elit ośrodków nadbałtyckich sygnalizuje problem, który poruszam w niniejszym artykule. Dotyczy on definicji terminów: skandynawski i wikiński, którymi się posługujemy w pracach dotyczących występowania elementów tych dwóch kultur (tj. skandynawskiej i wikińskiej) na ziemiach polskich w okresie wczesnego średniowiecza. Przedmioty te były materialnymi atrybutami elit ośrodków nadbałtyckich - ogniw transkontynentalnej strefy wymiany. Zakładam, że obydwie kultury, pomimo iż wyrosły z jednej wspólnej tradycji, reprezentują dwie różne formacje społeczne. Poruszenie tego zagadnienia wynika $\mathrm{z}$ faktu, iż pomimo stosunkowo licznych prac, które ukazały się w ostatnim okresie na temat interpretacji zjawiska występowania elementów materialnych kultur skandynawskiej i wikińskiej na ziemiach polskich (Żak 1967; Kara 1991; 1993; Duczko 2000; 2011; Jagodziński 2010; Moździoch 2011; Moździoch, Wiszewski i Stanisławski [red.] 2013; Urbańczyk 2014, s. 117-170; Stanisławski 2013; 2017) oraz źródeł pisanych dotyczących ziem polskich (w ich przypadku wyłącznie Pomorza) w okresie wikińskim (Morawiec 2010), zauważalna jest pewna swoboda $\mathrm{w}$ posługiwaniu się takimi terminami, jak: skandynawski, wikiński, normański, normandzki, ruski, wareski, a także różne rozumienie powyższych pojęć przez poszczególnych badaczy. Przejawem tego są także różne formy zapisów terminu wiking małą (w moich dotychczasowych publikacjach byłem zwolennikiem powyższej formy zapisu) lub wielką literą. Nierzadko przymiotniki skandynawski i wikiński są też błędnie stosowane w naszej literaturze jako synonimy. Uporządkowanie kwestii terminologicznych jest istotne ponadto $\mathrm{z}$ tego względu, iż przy obecnym stosunkowo zaawansowanym stanie badań nad występowaniem elemen- 
tów kultur skandynawskiej i wikińskiej na ziemiach polskich, brak precyzji terminologicznych może prowadzić do wypaczania bądź błędnego rozumienia ich wyników. Zdefiniowanie sformułowań, którymi się posługujemy, ma znaczenie także dla określenia celów naszych studiów. Decydują one bowiem, czy jest nim przedmiot - przejawem tego typu studiów są badania mające na celu określenie specyficznych cech (zazwyczaj materialnych) danego zespołu kulturowego, dla których możemy wskazać analogie na innych obszarach; czy też jest to podmiot w takim przypadku celem naszych badań będzie wyjaśnienie, z jakiego rodzaju formacjami społecznymi mamy do czynienia na danych stanowiskach w poszczególnych przedziałach czasu.

Dążenie do uporządkowania kwestii pojęciowych nie jest zresztą postulatem nowym. Można je bowiem dostrzec zarówno w starszej (Leciejewicz 1979), jak i najnowszej literaturze przedmiotu (Duczko 2007, s. 104-111; Urbańczyk 2000; 2008; 2012, 2014a, s. 91-101, 171-181; 2014b).

Jednym z uczestników dyskusji jest Władysław Duczko, który podjął się zdefiniowania znaczenia przymiotników: skandynawski, wikiński, ruski, wareski, normański i normański, omawiając je na wystąpieniach konferencyjnych oraz wykładach okolicznościowych. Uwagę szczególną zwrócił jednak na Rusów, identyfikując ten zagadkowy termin z migracjami mieszkańców środkowej Szwecji na obszary Europy Wschodniej (2007, s. 104-111). Władysław Duczko jest także autorem sugestii, istotnej dla niniejszego studium, że sama znajomość zabytków skandynawskich i używanie ich do interpretacji nie jest wystarczająca, aby zrozumieć okoliczności pojawienia się tych przedmiotów. Musimy dysponować także wiedzą na temat stosunków panujących na danym obszarze, w domyśle także relacji społecznych (2011, s. 64-65).

Głos w dyskusji na ten temat zabierał także kilkakrotnie Przemysław Urbańczyk (2000; 2008; 2012, 2014b), podsumowując swoje stanowisko w ostatniej publikacji (2014a). Uznał on za nieporozumienie przyjęcie w polskiej literaturze nazwy własnej „Wiking”, którą utarło się określać wczesnośredniowiecznych Skandynawów. Badacz podkreśla, że staroskandynawski víking określał organizowane przez Skandynawów (ale z częstym udziałem ludzi innego pochodzenia - np. Słowian) wyprawy łupieżczo-handlowe, charakterystyczne dla okresu VIII-XI wieku. Termin ten nie ma jednak konotacji etnicznej lub geograficznej, a oznacza pewien fenomen kulturowy. Wydzielony w dziejach Europy Północnej i Zachodniej Viking Age nie oznacza więc „epoki Wikingów”, lecz ,epokę wikingów”, czyli wypraw wikińskich. Ludzi tych cechowało jednak transregionalne podobieństwo na ogólnym poziomie wzorca stylu życia elit militarno-politycznych, ich języka i systemu wierzeń religijnych. Sugeruje on ponadto konieczność wyróżniania powstających w skandynawskich „diasporach” lokalnych tożsamości, np. „,wolińskiej” czy ruskiej (Urbańczyk 2014, s. 91-101, 171-181).

Nie mniej ważne propozycje pojawiły się jednak także w starszej polskiej literaturze. Lech Leciejewicz operował pojęciami: Normanowie oraz Wikingowie. Tym 
pierwszym określał germańskich mieszkańców Skandynawii (1979, s. 8). Terminem Wikingowie - mieszkańcy zatok od staronordyjskiego vík (zatoka) - posługiwał się jako specyficznym dla okresu wypraw Wikingów. Zdaniem Lecha Leciejewicza był to czas wielkiej konfrontacji Skandynawii ze światem zewnętrznym. U jego podstaw leżały przesłanki gospodarcze, społeczne i polityczne, spowodowane nimi migracje oraz kolejne następstwa $\mathrm{z}$ nich wynikające. W rezultacie zniszczeniu ulegały dotychczasowe formy współżycia społecznego (struktury rodowo-plemienne) oraz tworzył się nowy (feudalny) porządek ekonomiczny i społeczno-polityczny (1979, s. 8, 81, 87-88). Chociaż powyższe propozycje są pewnym uproszczeniem - modelem, zwracają one jednak uwagę nie tylko na kwestie ekonomiczne i polityczne, ale także na niezwykle ważne czynniki społeczne, które leżały u podstaw przemian dokonujących się wówczas w Skandynawii, a także skutkiem migracji Normanów również m.in. w strefie nadbałtyckiej oraz w konsekwencji na pewnych obszarach ziem polskich. W ich następstwie zarówno w Skandynawii, jak i na obszarach migracji Skandynawów tworzyły się nowe formacje społeczne - podmioty naszych studiów, których pochodną były kultury materialne, które tworzyli i którymi operowały te społeczności - przedmioty naszych badań. Na kwestie przemian społecznych, dokonujących się skutkiem migracji oraz powstające w ich wyniku nowe formacje społeczne chcę zwrócić też szczególną uwagę w przedstawionej poniżej propozycji zdefiniowania terminów: skandynawski i wikiński oraz ich konotacji.

Dotychczasowe studia nad występowaniem elementów kultur skandynawskiej i wikińskiej na ziemiach polskich zaowocowały wypracowaniem następującego modelu tego zjawiska. Normanowie przebywali na tym obszarze w trzech okresach. Pierwsza fala obecności ludzi Północy związana jest z powstawaniem w VIII i IX w. nadbałtyckiej strefy gospodarczej. Specyfiką tego systemu były osady rzemieślniczo-handlowe, zakładane zazwyczaj przez Duńczyków. Jedna z nich powstała nad jeziorem Drużno (Janów Pomorski) w IX stuleciu (Jagodziński 2010). Z kolei przybysze ze środkowej Szwecji osiedlili się nad dolną Parsętą na przełomie VIII i IX wieku. Pobyt przybyszów ograniczał się wówczas wyłącznie do ośrodków położonych na wybrzeżu. Normanowie pojawili się ponownie w 2. połowie X w. i w 1. połowie XI wieku. Skupili swoją uwagę wówczas głównie na rejonie ujścia Odry. Najważniejszym ośrodkiem na tym obszarze był gród w Wolinie. W tym okresie wikingowie nie ograniczali się jednak do pobytu wyłącznie w ośrodkach na wybrzeżu. W trzeciej tercji X w. wyruszali Odrą na południe w głąb ziem polskich. Ślady ich obecności odkryto na Pomorzu, w Wielkopolsce oraz na Śląsku. Po raz trzeci Normanowie pojawili się w XI i XII w. (pod koniec XII w. miała miejsce seria najazdów duńskich). Obecność przybyszów była wówczas ograniczona ponownie wyłącznie do ośrodków położonych na wybrzeżu. Ślady pobytu ludzi Północy w tym czasie są bardzo nikłe. Epizod ten znamy głównie ze skandynawskich źródeł pisanych. Powyższy model opisywanego zjawiska zaprezentowałem szerzej w osobnych pracach (Stanisławski 2013; 2017). 
Formacje społeczne występujące w ramach powyższego modelu proponuję wyjaśnić w ramach paradygmatu transmigracyjnego i transnarodowego, wypracowanego na gruncie socjologii (Krzyżowski i Urbańska 2010; Faist 2010; Geisler 2010; Andrejuk 2010). Transnarodowość jako zespół dyrektyw metodologiczno-teoretycznych jest obecnie intensywnie rozwijającym się kierunkiem studiów, w ramach badań nad współczesnymi zjawiskami migracji (Krzyżowski i Urbańska 2010, s. 9-13). Zwolennicy transnarodowych teorii próbują ponadto przezwyciężyć „metodologiczny terytorializm”, łączący społeczeństwo, państwo, terytorium oraz ograniczenia etniczne, wciąż obecne w studiach nad migracjami (Faist 2010, s. 31-32). Stosowane pojęcie ,transnarodowy” odwołuje się jednak do terminu „,narodowy”, określającego typ państw europejskich uformowanych wraz z podpisaniem Traktatu Westfalskiego (1648 r.). Wydaje się jednak, że paradygmat ten może być wykorzystany również do studiów nad migracjami epoki Wikingów, co chciałbym w tym artykule przedłożyć pod dyskusję. W przypadku studiów nad kulturami skandynawską i wikińską, osadzonymi w realiach wczesnego średniowiecza, proponuję jednak zastąpić termin „,narodowy” bardziej adekwatnym pojęciem „etniczny".

Formacje społeczne wyróżnione w ramach powyższego schematu systematyzującego obecność ludzi Północy na ziemiach polskich proponuję definiować w myśl przyjętego paradygmatu jako diasporę (Andrejuk 2010) skandynawską - w odniesieniu do osadnictwa występującego nad dolną Parsętą oraz w delcie Wisły w pierwszym okresie aktywności ludzi Północy na polskim południowym wybrzeżu Bałtyku, oraz jako transetniczną (Krzyżowski i Urbańska 2010; Faist 2010; Geisler 2010) społeczność wikińską - w przypadku drugiego okresu aktywności przybyszów z Północy na naszych ziemiach. Przy zastrzeżeniu jednak, które podkreślają przedstawiciele proponowanego kierunku, iż nie ma możliwości ścisłego wyraźnego rozdzielenia pojęć diaspora i społeczność transnarodowa (Andrejuk 2010, s. 79) /transetniczna.

Ludzi Północy, którzy stworzyli diaspory skandynawskie na południowym wybrzeżu, przybyli tam w większych grupach. Byli to osadnicy ze środkowej Szwecji, migrujący nad dolną Parsętę, oraz Duńczycy (ale najprawdopodobniej także Szwedzi i Gotlandczycy), którzy założyli osadę nad jeziorem Drużno. Sądząc, na podstawie zabytków odkrytych w tych dwóch miejscach, były to najprawdopodobniej całe grupy osadników skandynawskich, które tworzyli mężczyźni, kobiety i dzieci. Więzy rodzinne były zatem jedną z podstawowych relacji, jakie konstytuowały te społeczności. Migrantów w każdym z tych miejsc łączyło ponadto poczucie więzi wspólnego pochodzenia.

Wzorce kulturowe, które ze sobą przywieźli z Północy, kultywowali również na południowym wybrzeżu Bałtyku. Świadczy o tym kultura materialna odkryta na terenach obydwu kompleksów osadniczych. Na jej podstawie można dostrzec zarówno w Świelubiu-Bardach, jak i w Janowie Pomorskim przejawy aktywności w ramach różnych sfer kultury specyficznych dla Skandynawów. Przywiązanie imi- 
grantów do kultury kraju pochodzenia przez tak długi okres może świadczyć także o ich pewnego rodzaju konserwatyzmie. Mógł on być przejawem występującej u tych społeczności potrzeby przeciwstawienia się asymilacji do kultur społeczeństw przyjmujących (Słowian osiadłych nad dolną Parsętą, Bałtów w delcie Wisły). Jest to jedna $\mathrm{z}$ cech diaspory, polegająca na zachodzącym z jednej strony procesie asymilacji i integracji imigrantów do społeczeństwa przyjmującego, a $\mathrm{z}$ drugiej strony na dążeniu do podtrzymania odrębności społeczności migrantów i ich potomków (Andrejuk 2010, s. 81).

Długi okres pobytu tych społeczności w obydwu miejscach położonych na południowym wybrzeżu Bałtyku wskazuje, że byli to emigranci, którzy opuszczali kraj pochodzenia ze świadomością, że robią to na stałe. Nie planowali oni powrotu do ojczyzny. Była to zatem emigracja typowo osadnicza, czym charakteryzowało się również zasiedlanie przez Skandynawów wysp Atlantyku, np. Islandii. W przeciwieństwie jednak do wyludnionych lub prawie bezludnych wówczas terenów wysp Atlantyku osiedlali się oni na obecnych ziemiach polskich na terenach już zamieszkanych. Długi okres pobytu wśród obcych, który cechuje obydwie społeczności skandynawskie, jest także jedną z istotnych cech konstytuujących istnienie diaspory. Kolejną jej specyfiką jest wielopokoleniowość - przynajmniej część osobników tworzących diasporę (drugie pokolenie) wychowuje się od najmłodszych lat w nowym kraju osiedlenia (Andrejuk 2010, s. 72). Na zaistnienie wielopokoleniowości może wskazywać występowanie obcego osadnictwa na obydwu osadach przez długi czas.

$\mathrm{Z}$ innym typem formacji społecznej mamy do czynienia $\mathrm{w}$ drugim okresie aktywności ludzi Północy na ziemiach polskich, przypadającym na 2. połowę X stulecia i prawdopodobnie pierwsze dekady XI stulecia. Pierwsze ślady ich obecności w Wolinie datujemy na okres po roku 966, a na lata 80. i 90. X w. pojawienie się nad Dziwną kolejnej grupy przybyszów, na schyłek X i pierwsze dekady XI w. (a w niektórych ośrodkach, np. w Żółtem także w 2. połowie XI stulecia) aktywność tych ludzi w ośrodkach wczesnopiastowskich w Wielkopolsce, na Pomorzu i na Dolnym Śląsku (Stanisławski 2017). Społeczność tę identyfikuję przede wszystkim na podstawie występowania w Wolinie oraz w innych ośrodkach przedmiotów dekorowanych w specyficzny sposób - splotem pierścieniowo-łańcuchowym, należącym do repertuaru stylu Borre sztuki wikińskiej. Wyznacznikiem obecności tych ludzi w Wolinie jest przede wszystkim osiem zwartych kolekcji zabytków (Stanisławski 2013, s. 244-252). Znaleziska, które znamy z Wolina, tworzące zwarte kolekcje, posadowione w konkretnych i ściśle zdefiniowanych kontekstach, pozwalają nam zdefiniować tożsamość kulturową tych ludzi oraz zrekonstruować model ich kultury i proces jej formowania. Wspomniane kolekcje zabytków skandynawskich wystąpiły jednak zawsze wspólnie ze specyficznymi lokalnymi słowiańskimi elementami kultury materialnej (np. budownictwo mieszkalne, wytwórczość garncarska i rogownicza). Wśród zabytków identyfikowanych bezpośrednio z kulturą ludzi Północy są przedmioty, którym możemy przypisać 
zarówno pochodzenie duńskie, a także wytwory pochodzące lub inspirowane kulturą wikińską Wysp Brytyjskich, jak i wyroby specyficzne dla żywiołu skandynawskiego w Europie Wschodniej. Okres występowania opisywanego fenomenu w delcie Odry był znacznie krótszy niż wcześniejsze zjawisko obecności skandynawskiej nad dolną Parsętą oraz u ujścia Wisły. Kultura ta nie wykazała zatem zdolności do dłuższego trwania i po kilku dekadach zanikła. Proces formowania się opisywanej formacji społecznej przedstawia się następująco.

(1) Został on zainicjowany przez pewną grupę ludzi Północy, najprawdopodobniej Skandynawów lub Wikingów. Pojawili się oni w Wolinie po roku 966 i zajmowali się przypuszczalnie działalnością kupiecką (Stanisławski 2013, s. 244-246, 251). Ślady materialne wskazują, że społeczność tę tworzyli wyłącznie mężczyźni. Brak jest jakichkolwiek przesłanek materialnych, które wskazywałby, że była to cała społeczność, reprezentowana także przez kobiety i dzieci. Była to zatem grupa całkowicie odmienna od tych, które pojawiły się wcześniej nad dolną Parsętą i nad jeziorem Drużno, preferujących model życia w diasporze.

(2) Migranci przebywali w obcym autochtonicznym środowisku kulturowym. W przypadku Wolina była to lokalna społeczność słowiańska.

(3) Przybysze utrzymywali nadal stałe kontakty ze Skandynawią. Są one czytelne w źródłach materialnych głównie na płaszczyźnie powiązań handlowych. Ich świadectwem w Wolinie jest występowanie np. słoninca, a także ogromnych ilości fyllitu - dóbr pochodzenia norweskiego. W ich przypadku brak jednak przesłanek, które wskazywałby na bezpośrednie powiązania z Norwegią. Dobra te importowano - przez cały okres funkcjonowania opisywanej społeczności nad Dziwną przypuszczalnie za pośrednictwem powiązań z duńskim Hedeby. Równolegle widoczne są także regularne kontakty z Europą Wschodnią, prowadzone drogą morską. Ich świadectwem są występujące w Wolinie oraz w jego okolicach skarby srebra orientalnego. Kruszec był za pośrednictwem grodu w Wolinie dystrybuowany dalej szlakiem Odra-Warta-Noteć na tereny domeny wczesnopiastowskiej.

(4) Społeczność ta była zasilana przez nowych przybyszów. Ich pojawienie się w Wolinie jest widoczne w latach 80. X stulecia. Mogli to być kupcy, kupcy-wojownicy i wojownicy (Stanisławski 2013, s. 246-258). Niewykluczone, że zasilanie lokalnej społeczności przez nowych przybyszów następowało m.in. skutkiem banicji.

(5) Społeczność ta żyła w środowisku, w którym funkcjonował wodzowski model kultury. Możemy go identyfikować na podstawie źródeł pisanych, w których ukazano postać Wichmana - wodza wolinian, oraz literatury staroskandynawskiej. Szczególnie na kartach tej ostatniej - opiewającej Jómsborg i półlegendarną społeczność Jómswikingów, pojawiają się zarówno legendarni, jak i historycznie bohaterowie - wodzowie bractwa (Palnatoki, Sigwaldi, Styrbjörn). Na funkcjonowanie w Wolinie formacji wodzowskiej wskazuje także szereg cech dla niej specyficznych, które są uchwytne w kulturze materialnej. Są to np. struktura hierarchiczna uwypuklająca różnice statusu społecznego, występowanie domostw 
wyspecjalizowanych rzemieślników, istnienie stałego ośrodka ceremonialnego (Renfrew i Bahn 2002, s. 166-168). Jako przejawy pierwszej z powyższych cech można interpretować znaleziska przedmiotów kultury elitarnej (np. wyrobów dekorowanych zgodnie z kanonami sztuki wikińskiej w stylach Borre, Mammen i Ringerike, biżuterii); cechy drugiej to obecność obiektów-budynków, we wnętrzach których wystąpiły warsztaty rogownicze, skórnicze, snycerkie, bursztyniarskie, a także wyspecjalizowanej wytwórczości garncarskiej i artysty produkującego i zdobiącego przedmioty według manier sztuki wikińskiej; cechy trzeciej zaś to występowanie ośrodka kultowego na Srebrnym Wzgórzu - miejsca deponowania skarbów srebra - specyficznej formy obrzędowości ludzi Północy.

(6) Społeczność ta utrzymywała kontakty z innymi ośrodkami nadbałtyckimi i funkcjonowała w ponadetnicznym środowisku elit ośrodków nadbałtyckich. Elity te były zaangażowane $\mathrm{w}$ utrzymanie, obsługę i wymianę prowadzoną w nadbałtyckiej strefie gospodarczej, będącej elementem bałtycko-orientalnego systemu wymiany (jego elementami na wschodzie były szlaki nadwołżański i naddnieprzański), a nawet szerzej wielkiej arterii komunikacyjno-handlowej łączącej islamski Wschód oraz Bizancjum za pośrednictwem Europy Wschodniej i strefy nadbałtyckiej z imperium karolińskim na zachodzie, którą Michael McCormick nazwał Łukiem Północnym (McCormick 2009, s. 539-542, 582-588). Świadectwem mobilności oraz utrzymywania kontaktów z innymi ośrodkami są odkryte w Wolinie wraki łodzi, porty oraz dobra pochodzenia obcego (np. kruszec orientalny, fyllit, słoniniec, jedwab).

(7) Elementy kultury ludzi Północy występują w Wolinie w stosunkowo wąskim przedziale czasu (po roku 966 aż do ewentualnie początku/pierwszych dekad XI w.). Był to okres znacznie krótszy niż osadnictwo w diasporach skandynawskich nad dolną Parsętą oraz nad jeziorem Drużno.

Konstytuowanie się powyższej formacji społecznej łączyło się z zawieraniem i utrzymywaniem szeregu rodzajów relacji społecznych. Powiązania te wpływały na kulturę materialną, którą tworzyła i którą operowała opisywana społeczność. Kultury podmiotów, pomiędzy którymi zawiązywano relacje społeczne, rzutowały także na indywidualny/jednostkowy charakter kultury każdej społeczności wikińskiej.

(1) Pojawienie się obcych na nowym, już zamieszkanym obszarze (gród w Wolinie) spowodowało zawiązanie relacji pomiędzy przybyszami oraz lokalną społecznością słowiańską. Rezultatem było m.in. zaadaptowanie przez przybyszów lokalnych technik i form budownictwa mieszkalnego (domy o konstrukcji międzysłupowej), miejscowej ceramiki (naczyń produkowanych w technice całkowitego obtaczania, a także okazów typu Menkendorf) oraz dystrybucja przedmiotów pochodzenia skandynawskiego wśród autochtonicznej społeczności słowiańskiej. Zabytki o rodowodzie skandynawskim występujące $\mathrm{w}$ Wolinie są ponadto specyficzne wyłącznie dla kultury materialnej mężczyzn. Brak wśród nich oznak pobytu skandynawskich kobiet. Spostrzeżenie to dopuszcza pogląd, iż dochodziło 
tam również do wymiany z lokalną społecznością, celem pozyskania kobiet przez przybyszów. Analogiczny mechanizm mógł działać także na innych obszarach, na których pojawili się ludzie Północy. Różnorodność środowisk autochtonicznych powodowała w konsekwencji pierwszy poziom różnicowania kultur wikińskich, funkcjonujących na różnych obszarach. Na odmiennych lokalnych podłożach kulturowym były bowiem w użyciu różne miejscowe dobra i treści, będące przedmiotem wymiany pomiędzy przybyszami a autochtonami.

(2) Ludzie Północy przebywający w nowym obszarze poza ojczyzną utrzymywali nadal kontakty z krajem pochodzenia (świadectwem są np. ogromne masy fyllitu, a także słoniniec zarejestrowane w Wolinie) - dokąd były one cyklicznie dostarczane. W przypadku ludzi Północy przebywających w delcie Odry nie możemy jednak kategorycznie stwierdzić, czy przybyli oni bezpośrednio ze Skandynawii, a zwłaszcza z Danii (na co wskazuje szereg zabytków proweniencji duńskiej odkrytych w Wolinie), a nawet enklaw skandynawskich na Wyspach Brytyjskich (na co wskazywać może splot pierścieniowo-łańcuchowy specyficzny dla wyspy Man). Niewykluczone, że ludzie ci, zanim pojawili się w Wolinie, przebywali jakiś czas w skandynawskim środowisku kulturowym w Europie Wschodniej. Na tę ostatnią możliwość wskazuje szereg zabytków o proweniencji ruskiej odnotowanych w grodzie nad Dziwną (łódeczki z kory, jedwab, okucia i sprzączki do pasów, birki, pisanki kijowskie). Niewykluczone, że przybysze pochodzili z wszystkich trzech wymienionych powyżej obszarów. W rezultacie tych kontaktów utrzymywane były relacje pomiędzy osadnikami w Wolinie a społecznościami normańskimi w Skandynawii oraz na obszarach osadnictwa ludzi Północy (np. Europa Wschodnia). Specyfika kultur w krajach pochodzenia przybyszów, z którymi podtrzymywali oni nadal kontakty, generowała kolejny poziom zróżnicowania pomiędzy kulturami wikińskimi tworzonymi na różnych obszarach Europy.

(3) Opisywana społeczność została w latach $80 . \mathrm{X}$ w. zasilona przez nowych przybyszów. Zostały zawiązane kolejne relacje pomiędzy ludźmi Północy już zadomowionymi w Wolinie, wrosłymi w lokalne środowisko, a nową grupą imigrantów.

(4) Uprawianie żeglugi oraz kontakty handlowe utrzymywane $\mathrm{z}$ innymi ośrodkami nadbałtyckimi skutkowały zawiązywaniem relacji z elitami innych portów nadbałtyckich. Centra, do których wysyłano statki, miały również różny charakter. Były to zarówno emporia, osady na wybrzeżach, jak i punkty węzłowe - wyróżnione przez Sørena Sindbæk (jednym z nich był Wolin) (Sindbæk 2005). Punkty węzłowe położone były w miejscach, łączących różne strefy oraz typy komunikacji (w przypadku Wolina była to żegluga morska i kontakty z ośrodkami nadbałtyckimi oraz żegluga śródlądowa, łącząca gród nad Dziwną ze społecznościami zamieszkującymi dorzecza Odry, Warty i Noteci). W konsekwencji rozległość siatki połączeń komunikacyjnych i m.in. handlowych utrzymywanych $\mathrm{w}$ ramach nadbałtyckiej strefy wymiany oraz własnego zaplecza komunikacyjno-kulturowego, rzutowała na dalsze zróżnicowanie kultur wikińskich, występujących na różnych obszarach. 
(5) Funkcjonujący w Wolinie wodzowski model kultury skutkował zawieraniem relacji, specyficznych dla tego typu formacji społecznych (Renfrew i Bahn 2002, s. 166-168). Pozycja wodza była w nich uzależniona od ilości i jakości sojuszy, zawieranych z przedstawicielami elit. Zawiązywaniu sojuszy towarzyszyła z kolei symboliczna wymiana darów, której konsekwencją był przepływ pomiędzy Skandynawami a lokalnymi elitami słowiańskimi dóbr specyficznych dla tych dwóch społeczności. Mieszanie się oraz unifikacja kultury na poziomie materialnym (a może nie tylko?) dokonywała się zatem zarówno na poziomie relacji zawiązywanych w rezultacie związków konstytuujących formację wodzowską, jak i relacji już zawartych skutkiem samego pojawienia się obcych w nowym środowisku (wspomnianych powyżej w punkcie pierwszym).

Formację społeczną ukonstytuowaną wg opisanych powyżej mechanizmów oraz relacji społecznych możemy moim zdaniem próbować wyjaśniać w ramach zaproponowanego paradygmatu transmigracyjnego. Jego założenia oraz paralele pomiędzy modelami kultur transmigrantów oraz ludzi Północy przebywających na ziemiach polskich można scharakteryzować następująco.

Zwolennicy lansowanej perspektywy skupiają się na analizie praktyk społeczno-kulturowych, zachodzących w transnarodowych przestrzeniach społecznych. Transnarodowe przestrzenie społeczne są to kombinacje więzi i pozycji w sieciach oraz organizacjach, które funkcjonują w poprzek granic państwowych (Faist 2010, s. 30) (w przypadku realiów wczesnego średniowiecza bardziej adekwatnymi kategoriami pojęciowymi będą w tym wypadku granice etniczne, ewentualnie granice społeczności „plemiennych” lub władztw). W ich obrębie zachodzą gęste, cykliczne i stałe przepływy ludzi, dóbr, idei i symboli w poprzek granic, skutkiem których tworzą się więzi ponadnarodowe/ponadetniczne (przepływ ludzi, dóbr, idei i symboli jest doskonale udokumentowany w strefie nadbałtyckiej na płaszczyźnie materialnej poprzez znaleziska atrybutów kultur skandynawskich i wikińskich na południowym wybrzeżu morza; masowych znaleziskach specyficznych dla kultury słowiańskiej czytelnych w Skandynawii; dystrybucji kruszcu orientalnego zarówno w Skandynawii, jak i na południowym słowiańskim wybrzeżu Bałtyku). Kreowane powiązania społeczne oraz zachodzące pomiędzy nimi relacje rozchodzą się ponad granicami i obejmują kilka przestrzeni geograficznych, ponieważ codzienna przestrzeń życiowa migrantów składa się z wielu miejsc, ulokowanych w kilku krajach. Migranci poprzez swoją codzienną aktywność tworzą specyficzne obszary przekraczające granice - wspólnoty transnarodowe/transetniczne (Krzyżowski i Urbańska 2010, s. 11-12, 19; Faist 2010, s. 30; Geisler 2010, s. 53-54).

Podstawowym warunkiem wykreowania transetnicznych przestrzeni społecznych jest mobilność - migracja. Wynika ona z rozwoju technologicznego środków transportu i komunikacji oraz ich dostępności (np. powszechna znajomość szkutnictwa, morskie łodzie wikińskie, znajomość sztuki nawigacji, a także żegluga śródlądowa). Migracje były podyktowane również czynnikami społeczno-ekonomicznymi (np. czasowe banicje na okres trzech lat, wyprawy łupieżcze, wizyty na 
obcych zamorskich targach). Przemieszczanie się stanowi zatem strategię działania. Społeczność jest gotowa do nieustannej mobilności (Geisler 2010, s. 49-50, 56). Migracje mają zazwyczaj charakter czasowy, a nie stały (w przeciwieństwie do migracji, których skutkiem jest powstanie diaspory).

Migracje nie są traktowane jednak jako decyzje nieodwołalne. Członkowie takich społeczności urodzili się zazwyczaj w kraju wysyłającym, a nie przyjmującym. Brak tu zatem również typowej dla diaspory wielopokoleniowości - obecności ludzi urodzonych w drugim pokoleniu już w kraju przyjmującym.

Emigranci i uchodźcy, którzy osiedlili się na dłuższy czas poza swym krajem pochodzenia, często pozostają z nim w łączności. Powiązania te mają nieformalny charakter lub mogą być zinstytucjonalizowane (Krzyżowski i Urbańska 2010, s. 11-12).

W tak zdefiniowanej przestrzeni funkcjonują transmigranci - imigranci, których życie codzienne zależy od zmiennych połączeń w poprzek międzynarodowych granic, a ich identyfikacja wynika z relacji do dwóch i więcej państw/miejsc. Nie są oni gośćmi w kraju przyjmującym, ponieważ osiedlili się i zostali włączeni do ekonomicznych i politycznych instytucji, społeczności i wzorców życia codziennego kraju, w którym zamieszkują (np. w wyniku sojuszy zawieranych pomiędzy elitami w ramach formacji wodzowskiej, będąc członkami bractw/drużyn wojowników, należąc do kręgu otoczenia lokalnego władcy/wodza, organizując wyspecjalizowaną wytwórczość rzemieślniczą, tworząc targi i aranżując wymianę). Jednocześnie są oni przywiązani także do innych miejsc, poprzez łączność z krajem pochodzenia. Czynnikiem podtrzymującym więzi migrantów z relatywnie niemobilnymi członkami społeczności wysyłającej, jest religia wraz z całym systemem praktyk. Angażowanie się w praktyki religijne- potwierdza trwałe więzi migrantów z ludźmi z kraju pochodzenia. Budują oni też instytucje i wpływają na lokalne i państwowe wydarzenia w państwie, z którego wyemigrowali (Krzyżowski i Urbańska 2010, s. 12, 17). Przykładem ostatniego rodzaju aktywności mogłaby być aranżacja związków dynastycznych zawartych pomiędzy władcami władztwa piastowskiego z królami najpierw Szwecji, a następnie Danii, za sprawą poślubionej im Piastówny Świętosławy. Nie można wykluczyć również jakiejś roli opisywanej społeczności w występującym paralelnie, do okresu jej obecności w delcie Odry, zjawisku masowej migracji Słowian do Skandynawii (świadectwem tego fenomenu są występujące masowo w Skandynawii znaleziska ceramiki tzw. bałtycko-wendyjskiej, biżuterii słowiańskiej, pochówki słowiańskich kobiet oraz słowiańskie nazwy miejscowe na wyspach duńskich).

Trasmigrant nie dąży do stałego osiedlenia się w kraju docelowym, nie przywiązuje się również do jednego kraju, ale migruje z pewną regularnością. Jego życie cechuje brak stałości i zastanego miejsca życia. W sagach skandynawskich opiewających losy Jómsborga i Jómswikingów występują często wzmianki informujące, że dana postać przebywała tam dokładnie trzy lata - zazwyczaj na taki okres skazywano w Skandynawii na banicję). Konsekwencją tego może być z jednej strony postawa nieustannej negacji znaczeń, wartości i form symbolicznych 
obejmujących kulturę dawnego i nowego miejsca, z drugiej zaś poczucie, że jest on u siebie, funkcjonując zarówno w obrębie innych kulturach, jak i w środowisku, z którego się wywodzi, może prowadzić do rozluźnienia związków z krajem pochodzenia i identyfikacji z przestrzenią, w której żyje (Geisler 2010, s. 55). Konsekwencją tego może być płynna tożsamość imigrantów w społeczeństwach transnarodowych i ich związki zarówno ze społecznością wysyłającą, jak i przyjmującą (Andrejuk 2010, s. 73). Stały, cykliczny ruch transmigrantów „tam i z powrotem", podtrzymywanie łączności z krajem pochodzenia oraz ciągła wymiana dóbr, informacji i symboli pomiędzy mobilnymi i relatywnie niemobilnymi jednostkami w kraju pochodzenia, generują różnego typu transetniczne przestrzenie społeczne. Nieustannie dochodzi $\mathrm{w}$ nich do mieszania się ze sobą odrębnych prądów znaczeń, wartości, wzorców kulturowych i form symbolicznych. Rodzi się wówczas nowy typ kultury niezakotwiczony na jednym obszarze. Obejmuje on tradycję kraju wyjściowego (np. skandynawską - duńską, wyspiarską, ruską) i krajów docelowych (np. słowiańską, bałtyjską). Nie jest ona jednak związana z konkretnym krajem, językiem, wyznaniem religijnym, wspólnym pochodzeniem czy etnosem (Geisler 2010, s. 54-57). Przełożeniem działania powyższego mechanizmu na realia wczesnego średniowiecza może być kultura materialna ludzi Północy przebywających w Wolinie. Cechuje ją współwystępowanie zarówno skandynawskich, jak i autochtonicznych słowiańskich elementów kulturowych, które tworzą jedną całość. Są to zarówno przedmioty codziennego użytku (słowiańska ceramika, specyficzna lokalna forma budownictwa mieszkalnego), jak i przedmioty kultu (skandynawskie amulety - np. młoty Thora, but Vidara), ale także pismo runiczne oraz sztuka wikińska.

W procesie konstruowania, podtrzymywania i rozwijania transnarodowych przestrzeni społecznych główną rolę odgrywa kapitał społeczny. Kapitał ten spełnia cztery funkcje. Funkcja selektywna determinuje, kto będzie migrował (np. banici, najemnicy, kupcy, młodsi synowie niedziedziczący ziemi). Połączenia rodzinne, wspólnotowe oraz przyjacielskie są także przepustką do świata migracji. Funkcja dyfuzyjna wpływa na pojawienie się bądź też nie pod wpływem pozytywnych doświadczeń migracyjnych migracji łańcuchowej (takimi przykładami szczególnymi w dziejach ludzi Północy mogą być migracje ze środkowej Szwecji do Europy Wschodniej, a w okresie późniejszym Normandów z Normandii do południowej Italii). Funkcja pomostowa pozwala na podtrzymywanie łączności mobilnych jednostek z ich krajem pochodzenia. Funkcja adaptacyjna determinuje pomoc oraz możliwość szybszego dostosowania się nowych członków sieci migracyjnej do społeczeństwa przyjmującego. W zależności od struktur powyższych czterech aspektów kapitału społecznego, decydujących o kształcie łączności transnarodowych, wyróżnia się trzy formy transnarodowych przestrzeni społecznych: (1) transnarodowe grupy pokrewieństwa (głównym źródłem jej więzi jest zasada wzajemności; charakteryzuje ją podtrzymywanie norm społecznych i kontrola członków rodziny); (2) transnarodową wymianę cyrkularną (podstawą jej więzi jest 
wymiana; charakteryzuje ją eksploatacja zasobów wewnątrzgrupowych: język, silne i słabe więzi w sieciach rówieśniczych (współczesnym przykładem są sieci handlowe, np. chińscy, libańscy i indyjscy biznesmeni); oraz (3) rozprzestrzenioną solidarność w obrębie wspólnot transnarodowych (głównym źródłem więzi jest solidarność); charakteryzuje ją mobilizacja kolektywnych reprezentacji w obrębie więzi symbolicznych, np. religijnych, rodowych, etnicznych. Aktywność transnarodowa obejmuje powiązania ekonomiczne, kulturowe, społeczne i religijne (Krzyżowski i Urbańska 2010, s. 13; Faist 2010, s. 41).

Społeczności transnarodowe w przeciwieństwie do wspólnot diaspor posiadają ograniczoną zdolność trwałości i tylko sporadycznie doprowadzają do zakorzenienia się imigrantów w kraju przyjmującym (Andrejuk 2010, s. 72). Z taką sytuacją mieliśmy też do czynienia na ziemiach polskich, gdzie odnotowaliśmy dwie społeczności funkcjonujące przez stosunkowo długi okres w dwóch diasporach skandynawskich (nad dolną Parsętą oraz nad jeziorem Drużno), a także jedną społeczność, która przez stosunkowo krótki okres przebywała w Wolinie. W przypadku tej ostatniej wspólnoty model reprezentowanej przez nią kultury posiada szereg paraleli definiujących społeczności transetniczne. Omawiana ostatnia formacja społeczna nie stworzyła też diaspory. Za diasporę nie można uznać bowiem społeczności, które pomimo niskiej liczebności w porównaniu do innej grupy w kraju pobytu, miała swobodny dostęp do władzy, albo wręcz dominowała nad pozostałymi grupami etnicznymi (Andrejuk 2010, s. 83). Z taką sytuacją mieliśmy najprawdopodobniej do czynienia w przypadku społeczności o rodowodzie północnym, przebywającej w Wolinie, zwłaszcza w okresie po roku 980, kiedy to ośrodek ten mógł podlegać zwierzchności władztwa duńskiego w okresie rządów Haralda Sinozębego. Do kręgu ludzi władcy należeli najprawdopodobniej również migranci posługujący się przedmiotami dekorowanymi w stylu pierścieniowo-łańcuchowym, których ślady obecności odkryto w ośrodkach domeny wczesnopiastowskiej.

W rezultacie migracji Normanów powstawały poza Skandynawią nowe formacje społeczne. Sytuacje takie zaistniały również na południowym wybrzeżu Bałty$\mathrm{ku}$ na obszarach obecnych ziem polskich. W przypadkach kiedy mieliśmy do czynienia z przemieszczeniem się całych grup osadników, które łączyły więzy pokrewieństwa, wspólne pochodzenie oraz cel migracji - opuszczenie kraju pochodzenia na stałe i zamieszkanie na nowym obszarze, powstawały diaspory. Ich cechą charakterystyczną było kultywowanie tradycji kraju pochodzenia oraz konserwatyzm, przejawiający się w pielęgnowaniu wzorców kulturowych przodków. Na naszych ziemiach powstały dwie takie diaspory - jedna nad dolną Parsętą (Świelubie-Bardy), druga nad jeziorem Drużno (Janów Pomorski). W przypadku tych dwóch społeczności możemy mówić o diasporach skandynawskich kultywujących kulturę ludzi Północy.

Innego rodzaju formacje społeczne niż diaspory powstawały skutkiem migracji, których uczestnikami byli zazwyczaj wyłącznie mężczyźni (kupcy, najemni wojownicy, rzemieślnicy, artyści, banici), niepołączeni więzami pokrewieństwa oraz 
wspólnym pochodzeniem. Ludzie ci musieli zatem zawiązać nowe więzi społeczne konstytuujące ich społeczność. Ich podstawą był zazwyczaj wodzowski model kultury. Funkcjonowali oni ponadto wśród obcych etnicznie społeczności autochtonicznych. Celem ich migracji również nie była emigracja na stałe, lecz czasowy z założenia pobyt na obczyźnie (wyprawa na wiking, działalność handlowa, najemna służba wojskowa, banicja). Ludzi tych cechowały ponadto stan permanentnej mobilności oraz zakorzenienie $\mathrm{w}$ dwóch lub więcej przestrzeniach geograficzno -kulturowych. Opisywana forma migracji tworzyła nową rzeczywistość społeczną - transetniczną przestrzeń społeczną, która nie była związana z konkretnym miejscem (np. Wolinem), lecz obejmowała przestrzeń (m.in. strefę nadbałtycką), nie była związana już wyłącznie z jednym etnosem (Skandynawami), lecz objęła także inne etnicznie społeczności (np. Słowian), które zostały połączone w wyniku zachodzących relacji społecznych. Taką społeczność proponuję nazywać Wikingami. Zaprezentowany powyżej model kształtowania się omawianej społeczności wskazuje, że był to etnikon - odpowiednik starożytnych Ludów Morza i w związku z tym termin Wikingowie należy zapisywać wielką literą.

Społeczności wikińskie, funkcjonujące obok skandynawskich diaspor, powstawały i rozwijały się w różnych rejonach migracji ludzi Północy. Uważam, że mogły one zostać uformowane i egzystować według podobnego zakreślonego powyżej mechanizmu. Różniły się one jednak między sobą treściami ich transetnicznych kultur, które wynikały z konstytuujących je sieci relacji społecznych, kreowanych przez pochodzenie z różnych obszarów świata skandynawskiego (np. Norwegia, Dania, środkowa Szwecja, Gotlandia), zróżnicowania kultur społeczności autochtonicznych, wśród których przebywali transmigranci, oraz konstelacji ośrodków, które tworzyły sieci ich migracji-relacji. W ten sposób mogła powstać transetniczna mozaika przestrzeni społecznych świata Wikingów.

\section{BIBLIOGRAFIA}

Andrejuk K. 2010, Koncepcja diaspory w naukach społecznych, w: Mozaiki przestrzeni transnarodowych. Teorie - metody - zjawiska, red. Ł. Krzyżowski, S. Urbańska, Kraków, s. 70-88.

Duczko W. 2000, Obecność skandynawska na Pomorzu i stowiańska w Skandynawii we wczesnym średniowieczu, w: Salsa Cholbergensis. Kołobrzeg w średniowieczu, red. L. Leciejewicz, M. Rębkowski, Kołobrzeg, s. 23-44.

- 2007, Ruś wikingów. Historia obecności Skandynawów we wczesnośredniowiecznej Europie Wschodniej, Warszawa.

- 2011, Wikingowie i wczesnośredniowieczna Polska, w: Swoi i obcy w kulturze średniowiecza, red. M. Brzostowicz, M. Przybyła, J. Wrzesiński, Poznań-Ląd, s. 61-69.

Faist T. 2010, O transnarodowym przetwarzaniu granic, przestrzeni i mechanizmów spolecznych, w: Mozaiki przestrzeni transnarodowych. Teorie - metody - zjawiska, red. Ł. Krzyżowski, S. Urbańska, Kraków, s. 29-48.

Geisler M. 2010, Transmigrant i jego kultura w przestrzeni transnarodowej. Próba analizy podstawowych pojęć, w: Mozaiki przestrzeni transnarodowych. Teorie - metody-zjawiska, red. Ł. Krzyżowski, S. Urbańska, Kraków, s. 49-58. 
Jagodziński M. 2010, Truso. Między Weonodlandem a Witlandem, Elbląg.

Kara M. 1991, Z badań nad wczesnośredniowiecznymi grobami z uzbrojeniem z terenu Wielkopolski, w: Od plemienia do państwa. Śląsk na tle wczesnośredniowiecznej Stowiańszczyzny Zachodniej, red. L. Leciejewicz, Wrocław-Warszawa, s. 99-120.

- 1993, Sity zbrojne Mieszka I. Z badań nad składem etnicznym, organizacja i dyslokacja drużyny pierwszych Piastów, „Kronika Wielkopolska” 3(62), s. 33-47.

Kirpičnikow A.N., Dubov I.V., Lebedev G.S. 1986, Rus'i varjagi (rusko-skandinavskie otnošenija domongol'skogo vremeni, w: Slavjane i skandinavy, Moskva, s. 189-297.

Krzyżowski Ł. Urbańska S. 2010, Perspektywa transnarodowa w studiach migracyjnych, w: Mozaiki przestrzeni transnarodowych. Teorie - metody-zjawiska, red. Ł. Krzyżowski, S. Urbańska, Kraków, s. $9-25$.

Lebedev G.S. 1982, Der slawische Burgwall Gorodec bei Luga. Zum Problem der west- und ostslawischen Beziehungen, w: Beiträge zur Ur- und Frühgeschichte 2, Berlin, s. 225-238.

Leciejewicz L. 1979, Normanowie, Wrocław.

Łosiński W. 1972, Początki wczesnośredniowiecznego osadnictwa grodowego w dorzeczu dolnej Parsęty (VII-X/XI w.), Wrocław.

- 1975, Bardy-Świelubie, ein Siedlungskomplex in unteren Parsęta-Flussgebiet, „Archeologia Polona” 16, s. 199-219.

- 1988, Chronologia napływu najstarszej monety arabskiej na terytorium Europy, „Slavia Antiqua” 31, s. 93-181.

- 2008a, Pomorze - bardziej stowiańskie czy bardziej ,,baltyckie”?, w: Pomorze Zachodnie we wczesnym średniowieczu. Studia archeologiczne, Poznań, s. 125-141.

- 2008b, Rola kontaktów ze Skandynawia w dziejach gospodarczych Stowian nadbaltyckich, w: Pomorze Zachodnie we wczesnym średniowieczu. Studia archeologiczne, Poznań, s.143-169.

McCormick M. 2009, Narodziny Europy. Korzenie gospodarki europejskiej 300-900, Warszawa.

Morawiec J. 2010, Wolin w średniowiecznej tradycji skandynawskiej, Kraków.

Moździoch S. 2011, „Bodaj się Piastów rzady nam święcity”. Archeologia o początkach państwa piastowskiego, w: Populi terrae marisque, red. M. Rębkowski, S. Rosik, Wrocław, s. 67-81.

Renfrew C., Bahn P. 2002, Archeologia - teorie, metody, praktyka, Warszawa.

Sindbæk S.M. 2005, Ruter og rutinisering: vikingetidens fjernhandel i Nordeuropa, København.

Stanisławski B. 2013, Jómswikingowie z Wolina-Jómsborga. Studium archeologiczne procesu przenikania kultury skandynawskiej na ziemie polskie, Wrocław.

- 2017, Udziat wikingów w powstaniu państwa wczesnopiastowskiego, w: Spór o poczatki państwa polskiego - historiografia, tradycja, mit, propaganda, red. W. Drelicharz, D. Jasiak, J. Poleski, Kraków, s. 139-166.

Urbańczyk P. 2000, Normanowie, „Archeologia Żywa” 1/2 (14), s. 26.

- 2008, Nordmannowie, Normanowie i Norwegowie, w: A. Buko. W. Duczko red., Przez granice czasu. Ksiega jubileuszowa poświęcona Profesorowi Jerzemu Gąssowskiemu, Pułtusk, s. 489-497.

- 2012 Identities of the Saqaliba and the Russiyya in early Arabic sources, w: W. Pohl, C. Gantner, R. Payne, red. Visions of Community in the post-Roman World: the West, Byzantium and the Islamic World, 300-1100, Ashgate, s. 459-473.

- 2014a, Bliskie spotkania wikingów, Wodzisław Śląski.

- 2014b, Who were the early Rus'?, w: A. Makarov, A.E. Leontiev, red. Rus' in the $9^{\text {th }}-12^{\text {th }}$ centuries: Society, state, culture, Moscow-Vologda, s. 228-233.

Żak J. 1967, „Importy” skandynawskie na ziemiach zachodniostowiańsich od IX do XI wieku (część syntetyczna), Poznań. 